\title{
Comparison of Gleason scoring and the new grade-group system in prostate cancers: a 15-year retrospective study
}

\section{Prostat kanserlerinde Gleason skorlaması ile yeni grade-group sisteminin karşılaştırılması: 15 yıllık retrospektif bir çalışma}

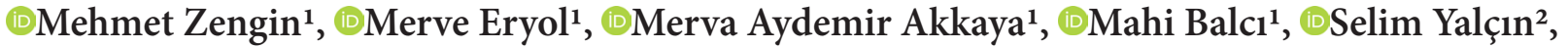 \\ 미 Devrim Tuğlu ${ }^{3}$
}

${ }^{1}$ Kırıkkale University, Department of Pathology, Kırıkkale, Turkey

${ }^{2}$ Kırıkkale University, Department of Internal Medicine, Kırıkkale, Turkey

${ }^{3}$ Kırıkkale University, Department of Urology, Kırıkkale, Turkey,

Cite this article as/Bu makaleye atıf için: Zengin M, Eryol M, Aydemir Akkaya M, Balcı M, Yalçın S, Tuğlu D. Comparison of Gleason scoring and the new grade-group system in prostate cancers: a 15-year retrospective study. J Health Sci Med 2020; 3(4): 382-388.

\begin{abstract}
Aim: Prostate cancer is the most common malignant tumour in men. The most widely used histological grading scheme for prostate cancer is Gleason scoring. After the original, this system has been modified several times. In this study, we retrospectively investigated the new Grade-group system (GGS).

Material and Method: This study includes 486 cases diagnosed with prostate cancer between 2000 and 2015. All cases were re-grouped for the new Grade-group system and its relationship with prognosis was examined.

Results: Grade-group system subgroups had a statistically significant relationship between prognostic factors and this relationship was more significant between GGS 2 and GGS 3 [tumor status $(\mathrm{p}<0.001)$, age $(\mathrm{p}=0.045)$, PN invasion $(\mathrm{p}<0.001)$, stage $(\mathrm{p}=0.004)$, and LN status $(\mathrm{p}<0.001)]$. In univariable survival analysis, there was a significant difference between Grade-group system subgroups (for GGS 2-GGS 3, RFS: $\mathrm{p}=0.035$ and OS: $\mathrm{p}=0.012$; for GGS 4-GGS 5, RFS: $\mathrm{p}=0.001$ and OS: $\mathrm{p}=0.001$ ). In multivariable survival analysis, GGS subgroups were found to be an independent survival parameter for prostate cancer (for GGS 2-GGS 3, OS: HR=2.56, $p=0.012$ and RFS: HR=2.69, $p=0.038$; for GGS 4-GGS 5, OS: HR=2.84, $\mathrm{p}=0.011$ and RFS: $\mathrm{HR}=2.59$, $\mathrm{p}<0.001$ ).

Conclusions: According to our results, the new Grade-group system performs the prognostic risk grading more accurately than the old classification. Also, the fact that this system contains fewer categories and is simpler has increased the interobserver compatibility.
\end{abstract}

Keywords: Grade-group system, Gleason scoring, prostate cancer.

\section{ÖZ}

Amaç: Prostat kanseri (PK) erkeklerde en sık görülen malign tümördür. PK için en yaygın kullanılan histolojik derecelendirme şeması Gleason skorlamasıdır. Orijinalinden sonra bu sistem birkaç kez değiştirildi. Bu çalışmada, prostat kanseri için tanımlanan yeni Grade-group sistemini (GGS) geriye dönük olarak inceledik.

Gereç ve Yöntem: Bu çalışma 2000-2015 yılları arasında prostat kanseri tanısı konmuş 486 vakayı içermektedir. Tüm olgular yeni Gradegroup sistemini için yeniden gruplandırıldı ve prognozla ilişkisi incelendi.

Bulgular: Grade-group sistemini alt gruplarının prognostik faktörler arasında istatistiksel olarak anlamlı bir ilişki vardı ve bu ilişki GGS 2 ve GGS 3 arasında daha anlamlı idi [tümör durumu ( $\mathrm{p}<0,001)$, yaş ( $\mathrm{p}=0,045)$, PN invazyonu $(\mathrm{p}<0,001)$, evre ( $\mathrm{p}=0,004)$, ve LN durumu $(\mathrm{p}<0,001)]$. Tek değişkenli sağkalım analizinde Grade-Group sistemini alt grupları arasında anlamlı bir fark vardı (GGS 2-GGS 3, RFS: $\mathrm{p}=0.035$ ve OS: $\mathrm{p}=0.012$; GGS 4-GGS 5, RFS için: $\mathrm{p}=0,001$ ve OS: $\mathrm{p}=0,001)$. Çok değişkenli sağkalım analizinde Grade-Group sisteminin alt gruplarının prostat kanseri için bağımsız bir sağkalım parametresi olduğu bulundu (GGS 2-GGS 3, OS: HR=2,56, p=0,012 ve RFS: HR=2,69, $\mathrm{p}=0,038$; GGS 4- için GGS 5, OS: $\mathrm{HR}=2,84, \mathrm{p}=0,011$ ve RFS: $H R=2,59$, $\mathrm{p}<0,001$ ).

Sonuçlar: Çalışmamıza göre, yeni Grade-group sistemini sistemi prognostik risk sınıflandırmasını eski sınıflandırmadan daha doğru bir şekilde gerçekleştirmektedir. Ayrıca, bu sistemin daha az kategori içermesi ve daha basit olması, gözlemciler arası uyumluluğu artırdı.

Anahtar Kelimeler: Grade-grup sistemi, Gleason skorlaması, prostat kanseri. 


\section{INTRODUCTION}

Prostate cancer (PC) is one of the most common cancers worldwide. In 2018, 1,276,106 new PC cases were detected. Mortality rates for PC are reported as $9.3 \%$ and its incidence increases with age (1). The most common subtype of PC is acinar adenocarcinoma. PCs are usually multifocal and mostly originate from the peripheral region of the gland. Considering the incidence and heterogeneous clinical behaviour of prostate carcinoma, it is very important to classify patients according to the risk group correctly $(1,2)$. Several clinical and pathological parameters (Gleason score [GS], serum prostate-specific antigen [PSA] level, radiological assessment, the status of surgical margin, regional lymph nodes, tumour stage, etc.) are used to identify risk groups. Among these factors, the GS system is still one of the most important prognostic parameters for the PC today $(2,3)$.

Gleason scoring system was defined by Donald F. Gleason in the 1960s (4). This classification is based on the architectural structure of the glands. Gleason drew a basic diagram for this classification by visualizing five different patterns of the tumour. In this system, the most common first and second patterns of 5 different patterns are summed and the total GS is given. This system is performed by histopathological evaluation of hematoxylin and eosin (H\&E) stained sections in $\mathrm{x} 4$ and $\mathrm{x} 10$ magnification. Modifications were made to this system in 1974 and $2005(5,6)$. Lastly, in 2013, the foundation of a Grade-group system (GGS) was laid with a study from Johns Hopkins Hospital. In this study, Epstein et al. (7) proposed dividing GS into prognostic risk categories. Thus, this system groups classic GS cases from 1 to 5 . This new rating system, which was later approved by many multicenter studies, was accepted at the 2014 International Society of Urological Pathology (ISUP) conference and entered WHO in 2016 (3).

In this study, we analyzed this new system retrospectively in terms of prognosis prediction, usefulness, and contribution to daily practice.

\section{MATERIAL AND METHOD}

\section{Ethical Approval}

The study was approved by the Kirkkale University Health Research Ethics Committee (Permission granted/ date: 2020, decision number: 2020.06.18). In this retrospective study, all procedures and practices are in accordance with the ethical standards of the national/ institutional research committee and the 1964 Helsinki declaration.

\section{Study Design}

This study was carried out in Kurıkkale University Faculty of Medicine, Department of Pathology. All patients who underwent biopsy and resection due to PC between 2000 and 2015 were included in this study. Patients with second malignancy synchronized with PC were excluded from the study $(n=9)$. Also, cases with tumour block deficiency $(n=10)$ and insufficient tissue in the block $(n=7)$ were excluded from the study. As a result, four hundred and eighty-six cases were collected. Tumour location and volume, GS, age, lymph node status, perineural and vascular invasion, stage, surgical margin, and survival information were recorded from the archive data.

\section{Processing of Tissues}

Necessary formalin-fixed paraffin-embedded tumour samples were collected from the tissue archives of the pathology department for cases deemed necessary $(\mathrm{n}=98)$. 4-micron thick sections prepared from paraffin blocks of these tissue samples were stained with $\mathrm{H} \& \mathrm{E}$.

\section{Assessment of Gleason Grade Group}

In this study, archive records, H\&E painted sections, conventional light microscope (Nikon Eclipse E600, Nikon AG Instruments, USA), and $\mathrm{x} 4-\mathrm{x} 10$ lenses were used for evaluation. Three experienced pathologists re-evaluated all cases. The scores of the cases varying between 2 and 10 were re-grouped in terms of GGS. GS $\leq 6$ patients were GGS1 group, GS $3+4=7$ patients GGS2 group, GS $4+3=7$ patients GGS3 group, GS 8 patients GGS4 group and GS 9-10 patients GGS5 group. The relationship between GGS and clinicopathological parameters was evaluated statistically. American Cancer Joint Committee $\left(8^{\text {th }}\right)$ guidelines were used in evaluations.

\section{Reproducibility of the study}

Inter-observer agreement was investigated to assess reproducibility. Three experienced pathologists (MZ, ME and MAA) evaluated all cases without knowing the clinical and pathological information. Kappa test (K), which is a variance ratio, was used for inter-observer agreement. $\mathrm{K}$ was grouped as weak, medium and perfect for values of $0.41-0.60,0.61-0.80$ and $0.81-1$, respectively.

\section{Patients follow-up}

The survival data for the outcome measures were obtained from the archive records. The start time was calculated from the day of the primary biopsy. 15 years of followup was considered appropriate to make a more reliable decision about the relapse of the disease. Recurrencefree survival (RFS) was defined as the time from primary biopsy day to local/regional recurrence day or death day. Overall survival (OS) was defined as the time from the day of primary biopsy to the day of death. All events after sixty months of follow-up were censored in sixty months.

\section{Statistical Evaluation}

Ranges, averages, and standard deviation were used to define continuous data and percentages and frequencies for categorical data. Chi-square test was used to analyze 
the relationships between clinicopathological prognostic factors and categorical variables. Significant differences between univariable survival groups were evaluated by the Log-rank test and survival curves were presented by the Kaplan-Meier method. Multivariable survival groups were evaluated by the Cox-regression model with a $95 \%$ confidence interval (CI) and a 1.0 hazard ratio (HR). All tests were two-sided and $\mathrm{p}$ values less than 0.05 were considered statistically significant. Statistical data were analyzed using SPSS 21.0 (IBM institute, North Castle, USA).

\section{RESULTS}

\section{General Features}

The mean of age and tumor volume were $65.54 \pm 8.77$ (range: $50-89$ ) and $4.50 \mathrm{~cm} \pm 1.50 \mathrm{~cm}$ (range: $2 \mathrm{~cm}-5 \mathrm{~cm}$ ). $135(27.7 \%)$ of tumors were GGS 1, 120 (24.6\%) were GGS 2, 114 (23.4\%) were GGS 3, 60 (12.3\%) were GS 4, and $57(11.7 \%)$ were GS 5. Tumour was single lobe in $291(60.0 \%)$ cases, and of tumour ratio was $<50 \%$ in 310 $(63.9 \%)$ cases.

\section{Evaluation of GGS}

Particular attention was paid when reassessing GS $3+4$ and $4+3$ cases because the GGS scores would be different. In general, our GS scores were compatible with archive records. There was a statistical relationship between GGS subgroups and prognostic factors, and there was more significant relationship, especially between GGS 2 and GGS 3 [tumour status $(\mathrm{p}<0.001)$, age $(\mathrm{p}=0.045)$, PN invasion $(\mathrm{p}<0.001)$, stage $(\mathrm{p}=0.004), \mathrm{LN}$ status $(\mathrm{p}<0.001)$, and surgical margin $(\mathrm{p}=0.003)]$. The statistical relationship between clinicopathological features and GGS is shown in Table 1.

\section{Reproducibility of GGS}

The inter-observer agreement was generally in the clinically useful range and ranged from moderate to significant $(\mathrm{k}=0.51-0.70)$. We also found that the agreement between observers for GGS is generally higher $(\mathrm{k}=0.63-0.70)$.

\section{Follow-up of Patients}

In the follow-up, one hundred and sixty-five cases died ( $\mathrm{n}=25$ for GGS1, n=89 for GGS 2 and GGS 3, n=51 for GGS 4 and GGS 5) and two hundred and ninety cases relapsed ( $\mathrm{n}=32$ for GGS $1, \mathrm{n}=96$ for GGS 2 and GGS 3, $\mathrm{n}=62$ for GGS 4 and GGS 5). The 5-year RFS and OS rates were $81 \%$ and $83 \%$ for GGS 2 and $65 \%$ and $66 \%$ for GGS 3 , respectively. Also, the 5-year RFS and OS rates were $55 \%$ and $58 \%$ for GGS 4 and $42 \%$ and $43 \%$ for GGS 5, respectively (Table 2).

\section{Survival Analyses}

There was a significant difference in survival in univariate analysis for GGS subgroups (for GGS 2-GGS 3, RFS: $\mathrm{p}=0.035$ and OS: $\mathrm{p}=0.012$; for GGS 4-GGS 5, RFS: $\mathrm{p}=0.001$ and OS: $p=0.001$ ) (Table 2, Figure 2). Other parameters associated with poor survival were LN status, stage, and surgical margin. GGS subgroups were an independent survival parameter for survival in multivariate analysis (for GGS 2-GGS 3, OS: HR=2.56 [1.81-4.32], $\mathrm{p}=0.012$ and RFS: $\mathrm{HR}=2.69$ [1.49-4.52], $\mathrm{p}=0.038$; for GGS 4-GGS 5, OS: $\mathrm{HR}=2.84$ [1.34-3.49], $\mathrm{p}=0.011$ and RFS: $\mathrm{HR}=2.59$ [1.46-4.19], $\mathrm{p}<0.001)$. Other independent parameters associated with poor survival were LN status, stage and surgical margins (Table 2).

Table 1. Statistical relationship of GGS subgroups with prognostic factors

\begin{tabular}{|c|c|c|c|c|c|c|c|}
\hline & & \multicolumn{3}{|c|}{ GGS (\%) } & \multicolumn{3}{|c|}{ GGS (\%) } \\
\hline & & GGS 2 & GGS 3 & p-value & GGS 4 & GGS 5 & p-value \\
\hline \multirow{2}{*}{ Tumour status } & Single lobe & $39(32.5)$ & $72(63.1)$ & \multirow{2}{*}{$<0.001^{*}$} & $22(36.6)$ & $33(57.8)$ & \multirow{2}{*}{$0.021^{*}$} \\
\hline & Both lobes & $81(67.5)$ & $42(36.9)$ & & $38(63.4)$ & $24(42.2)$ & \\
\hline \multirow{2}{*}{ Age } & $<65$ & $57(47.5)$ & $69(23.4)$ & \multirow{2}{*}{$0.045^{\star}$} & $27(45.0)$ & $36(63.1)$ & \multirow{2}{*}{$0.048^{*}$} \\
\hline & $\geq 65$ & $63(52.5)$ & $45(76.6)$ & & $33(55.0)$ & $21(36.9)$ & \\
\hline \multirow{2}{*}{ AL invasion } & No & $54(45.0)$ & $63(55.2)$ & \multirow{2}{*}{0.116} & $29(48.3)$ & $30(52.6)$ & \multirow{2}{*}{0.642} \\
\hline & Yes & $66(55.0)$ & $51(44.8)$ & & $31(51.7)$ & $27(47.4)$ & \\
\hline \multirow{2}{*}{ PN invasion } & No & $54(45.0)$ & $78(68.4)$ & \multirow{2}{*}{$<0.001^{*}$} & $29(48.3)$ & $38(66.6)$ & \multirow{2}{*}{$0.045^{*}$} \\
\hline & Yes & $66(55.0)$ & $36(31.6)$ & & $31(51.7)$ & $19(33.4)$ & \\
\hline \multirow{2}{*}{ Tumour volume } & $<50 \%$ & $54(45.0)$ & $63(55.2)$ & \multirow{2}{*}{0.116} & $24(40.0)$ & $34(59.6)$ & \multirow{2}{*}{$0.033^{*}$} \\
\hline & $\geq 50 \%$ & $66(55.0)$ & $51(44.8)$ & & $36(60.0)$ & $23(40.4)$ & \\
\hline \multirow{2}{*}{ Stage } & PT1 & $48(40.0)$ & $72(63.1)$ & \multirow{2}{*}{0.004} & $23(38.3)$ & $37(64.9)$ & \multirow{2}{*}{$0.004^{*}$} \\
\hline & PT2 & $72(60.0)$ & $52(36.9)$ & & $37(61.7)$ & $20(35.1)$ & \\
\hline \multirow{2}{*}{ LN status } & Negative & $52(35.0)$ & $81(71.0)$ & \multirow{2}{*}{$<0.001^{*}$} & $24(40.0)$ & $38(66.6)$ & \multirow{2}{*}{$0.003^{*}$} \\
\hline & Positive & $78(65.0)$ & $33(29.0)$ & & $36(60.0)$ & $19(33.4)$ & \\
\hline \multirow{2}{*}{ Surgical margin } & Negative & $52(35.0)$ & $72(63.1)$ & \multirow{2}{*}{$0.003^{*}$} & $22(36.6)$ & $35(61.4)$ & \multirow{2}{*}{$0.007^{*}$} \\
\hline & Positive & $78(65.0)$ & $52(36.9)$ & & $38(63.4)$ & $22(38.6)$ & \\
\hline
\end{tabular}




\begin{tabular}{|c|c|c|c|c|c|c|c|c|}
\hline & \multicolumn{4}{|c|}{ Univariate survival analysis(\%) } & \multicolumn{4}{|c|}{ Multivariate survival analysis(\%) } \\
\hline & \multicolumn{2}{|c|}{ OS } & \multicolumn{2}{|c|}{ RFS } & \multicolumn{2}{|l|}{ OS } & \multicolumn{2}{|l|}{ RFS } \\
\hline & 5-year (\%) & p-value & 5 -year (\%) & p-value & HR (95\% CI) & p-value & HR (95\% CI) & p-value \\
\hline Tumour status & & 0.248 & & 0.233 & & NC & & NC \\
\hline Single lobe & $89 \%$ & & $88 \%$ & & - & & - & \\
\hline Both lobes & $78 \%$ & & $77 \%$ & & - & & - & \\
\hline Age & & 0.457 & & 0.449 & & NC & & NC \\
\hline$<65$ & $85 \%$ & & $86 \%$ & & - & & - & \\
\hline$\geq 65$ & $75 \%$ & & $84 \%$ & & - & & - & \\
\hline AL invasion & & 0.559 & & 0.489 & & NC & & NC \\
\hline No & $87 \%$ & & $88 \%$ & & - & & - & \\
\hline Yes & $79 \%$ & & $88 \%$ & & - & & - & \\
\hline PN invasion & & 0.162 & & 0.168 & & $\mathrm{NC}$ & & $\mathrm{NC}$ \\
\hline No & $87 \%$ & & $87 \%$ & & - & & - & \\
\hline Yes & $75 \%$ & & $76 \%$ & & - & & - & \\
\hline Tumour volume & & 0.667 & & 0.823 & & $\mathrm{NC}$ & & $\mathrm{NC}$ \\
\hline$<50 \%$ & $88 \%$ & & $87 \%$ & & - & & - & \\
\hline$\geq 50 \%$ & $79 \%$ & & $80 \%$ & & - & & - & \\
\hline Stage & & $0.007^{\star}$ & & $0.009^{*}$ & & $0.041^{*}$ & & $0.032^{*}$ \\
\hline PT1-2 & $90 \%$ & & $89 \%$ & & 1 & & 1 & \\
\hline PT3-4 & $73 \%$ & & $73 \%$ & & $1.42(1.23-4.56)$ & & $1.37(1.33-2.44)$ & \\
\hline LN status & & $0.003^{*}$ & & $0.001^{*}$ & & $0.021^{*}$ & & $0.014^{*}$ \\
\hline Negative & $79 \%$ & & $78 \%$ & & 1 & & 1 & \\
\hline Positive & $63 \%$ & & $60 \%$ & & $1.31(1.11-4.12)$ & & $1.43(1.52-3.88)$ & \\
\hline Surgical margin & & $0.005^{\star}$ & & $<0.001^{\star}$ & & $0.0017^{\star}$ & & $0.003^{*}$ \\
\hline Negative & $88 \%$ & & $89 \%$ & & 1 & & 1 & \\
\hline Positive & $72 \%$ & & $70 \%$ & & $1.42(1.28-2.16)$ & & $1.54(1.37-3.62)$ & \\
\hline GGS & & $0.012^{\star}$ & & $0.003^{*}$ & & $0.038^{*}$ & & $0.012^{\star}$ \\
\hline GGS 2 & $83 \%$ & & $81 \%$ & & 1 & & 1 & \\
\hline GGS 3 & $66 \%$ & & $65 \%$ & & $2.56(1.81-4.32)$ & & $2.69(1.49-4.52)$ & \\
\hline GGS & & $0.001^{\star}$ & & $<0.001^{\star}$ & & $0.011^{\star}$ & & $0.001^{*}$ \\
\hline GGS 4 & $58 \%$ & & $55 \%$ & & 1 & & 1 & \\
\hline GGS 5 & $43 \%$ & & $42 \%$ & & $2.84(1.34-3.49)$ & & $2.59(1.46-4.19)$ & \\
\hline
\end{tabular}
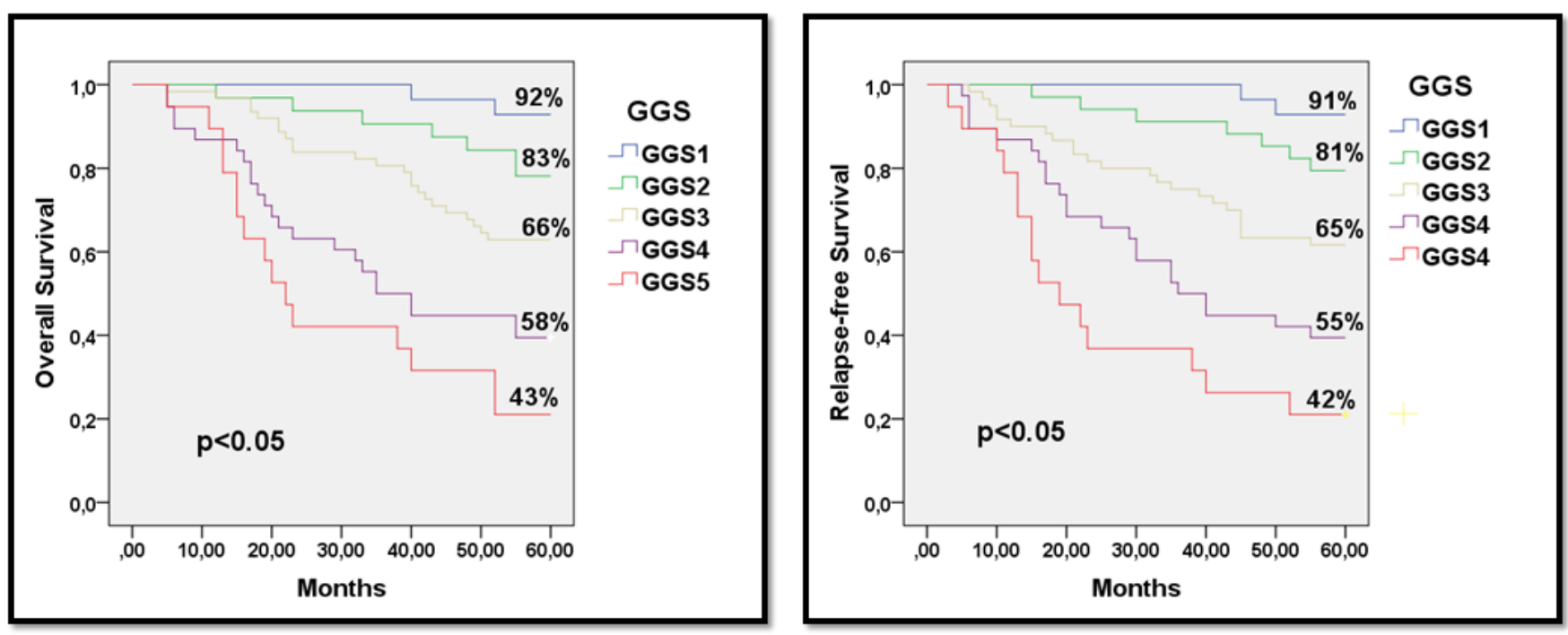

Figure 2: Overall survival and relapse-free survival of Grade-Group system

Survival curves were presented with the Kaplan-Meier curves. The limit of significance was accepted as 0.05 for the Chi-square test. 


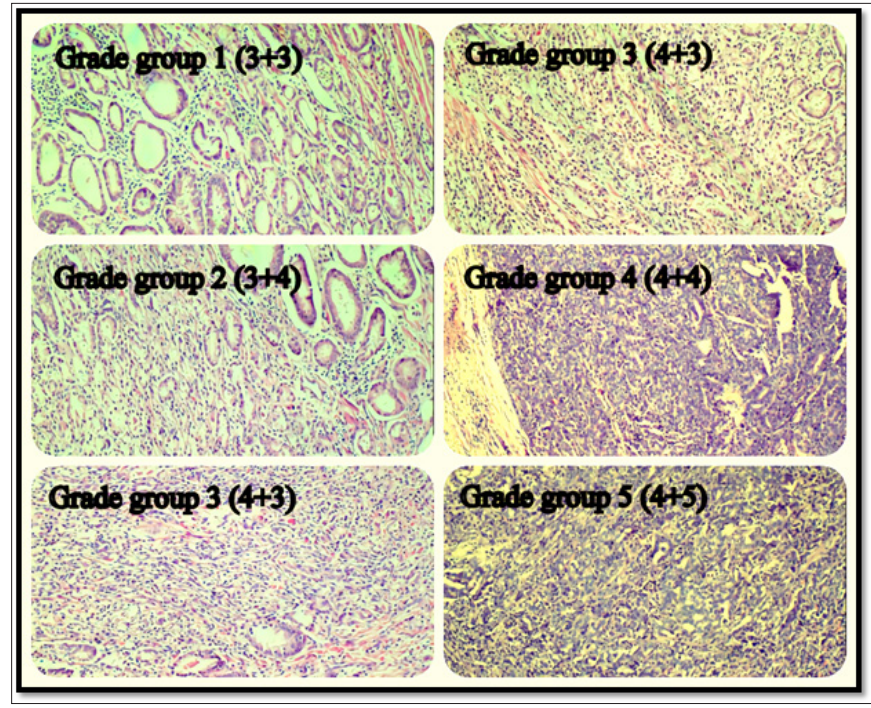

Figure 1. Representative examples of Grade-Group system (GGS) While examining prostate cancers in terms of GGS, x10-x20 lens, hematoxylin and eosin-stained sections, and classical microscope were used.

\section{Table 3. Reproducibility of GGS}

\begin{tabular}{lc} 
N & Kappa values (Weighted) \\
\hline GGS & $0.70(\mathrm{~A} \& \mathbf{B}), 0.62(\mathbf{B} \& C), 0.63(\mathrm{~A} \& C)$ \\
GS & $0.55(\mathbf{A \& B}), 0.51(\mathbf{B} \& C), 0.53(\mathbf{A} \& C)$
\end{tabular}

Abbreviations GS: Gleason scoring, GGS: Grade-Group system, A: First observer, B: Second observer, C: Third observer

\section{DISCUSSION}

In this study, we compared the new GGS with the old system. According to our findings, this system classified patients more accurately in terms of survival. Also, due to the simplicity of the GGS, this system increased the interobserver agreement.

Prostate cancer is one of the most common malignant tumours in the world and methods such as serum PSA level, transrectal prostate needle biopsy, and prostate ultrasound are used for its screening and diagnosis. Treatment options for PC are radical prostatectomy, chemotherapy, radiotherapy and hormonotherapy (8). The characteristics of the tumour should be evaluated correctly at the time of diagnosis for the correct treatment selection and correct prognosis estimation (9). While PC patients are divided into risk groups, GS and preoperative PSA level are very important $(10,11)$. Between these two factors, the final GS may change before and after surgery. Therefore, much attention should be paid to the correct evaluation of GS at the time of diagnosis for an appropriate treatment decision $(12,13)$.

Gleason scoringis a rating system developed in the 1960 s and remains the strongest prognosis estimator for PC today. GS was first modified from its original definition in 1974 by Gleason and Mellinger (5). In 2005, the 2nd modification was made by the ISUP, thereby achieving a better correlation between the Gleason degree, patient stage, and biochemical PSA values (6). Although these new changes were more complex than before, they showed better relationships with prognostic factors. As an example of the complexities, low-grade cancer, which covers less than $5 \%$ in needle biopsy of highgrade cancer, would not be included in GS (14). Also, the highest grade pattern was included in the biopsy score, but not in the resection score. However, many studies reported that GS 6 cases with pattern 4 differ in recurrence.That is, GS 6 cases with a high-grade component had a prognosis between GS 6 and GS $3+4=7(15,16)$. In our study, we experienced that the GS system is more complex. Also, the prognosis of the groups containing pattern 4 was worse than pattern 3 .

The last modification for the GS was made by ISUP in 2014. Accordingly, considering approximately 20000 radical prostatectomy data collected from different centres, PCs were categorized into 5 histological classes described above. Also, many multicenter studies have confirmed that GGS classifies PC patients more accurately in terms of prognosis (3). In addition, with the new grading system, the score that could have a value between 2-10 was reduced to 5 and a simpler stratification was created. Moreover, it was provided to express low and medium risk groups more easily (10, 13). In our study, it was seen that this system was easy to understand and useful. Also, the agreement between observers was higher. The GS $3+4$ and GS $4+3$ groups are scored as 7 in the GS system. However, studies have shown that the percentage of pattern 4 adversely affects patient prognosis in GS 7 patients. In the new system, GS $3+4=7$ cases are considered as GGS2, and GS $4+3=7$ cases are considered as GGS3 (17-19). In our study, we also found that GGS 3 has a worse prognosis than GG2.

In tumours with a GS score of 8 and above, the prognosis is significantly worse, but this is more pronounced at the 9-10 level. GS 8 and above are considered as a single category in most studies, including prediction tables and nomograms (20). This is because the number of patients with GS 9-10 is small and combined with GS 8 for meaningful statistical analysis. For this reason, some urologists consider GS 8 the same as GS 9-10. GS 9-10 patients are rarely seen, but GS 9-10 tumours have a worse prognosis than GS 8. Also, patients with these tumours are mostly not suitable for resection $(20,21)$. In addition, there is a significant decrease in prognosis in the first three years in GS 9-10 patients. For the above reasons, GS 9-10 patients should be evaluated separately from GS8 patients $(21,22)$. In our study, a significant difference was also observed between these two groups in terms of prognosis. 
The limitations of our study are as follows. Since our study is retrospective, there are some limitations inherent in retrospective studies. For example, it is not possible to overcome the sampling difference. Also, archive records were used for our study and individual records were not used. In addition, since our patients were treated according to protocols before 2015, there may be differences according to current treatment approaches.

\section{CONCLUSION}

According to our results, the new GGS divides patients more accurately into risk groups. Also, this system is very simple and this is an important advantage for daily practice, observers agreement and patient management.

\begin{abstract}
Abbreviations
PC: Prostate cancer, GS:Gleason scoring, GGS:GradeGroup system, HPF: High power field, ISUP: International Society of Urological Pathology, AJCC: American Joint Cancer Committee, k: Kappa, H\&E: Hematoxylin and eosin, SD:Standard deviation, HR: Hazard ratio, OS: Overall survival, RFS: Relapsefree survival
\end{abstract}

\section{ETHICAL DECLARATIONS}

Ethics Committee Approval: Our study was approved by the Kirıkkale University Health Research Ethics Committee (Permission granted/date: 2020, decision number: 2020.06.18). Attention has been paid to ensure that all steps performed during our study comply with the 1964 Helsinki Declaration and national/institutional ethical standards

Informed Consent: Because the study was designed retrospectively, no written informed consentform wasobtained from patients.

Referee Evaluation Process: Externally peer-reviewed.

Conflict of Interest Statement: The authors have no conflicts of interest to declare.

Financial Disclosure: The authors declared that this study has received no financial support.

Author Contributions: All of the authors declare that they have all participated in the design, execution, and analysis of the paper, and that they have approved the final version.

Acknowledgements: We would like to thank the staff of the Department of Pathology and Internal Medicine for their contribution to this research.

\section{REFERENCES}

1. Siegel RL, Miller KD, Jemal A.Cancer statistics, 2017. CA Cancer J Clin 2017; 67: 7-30.

2. Miller KD, Siegel RL, Lin CC, et al. Cancer treatment and survivorship statistics, 2016. CA Cancer J Clin 2016; 66: 271-89.

3. Epstein JI, Egevad L, AminMB, et al. The 2014 International Society of Urological Pathology (ISUP) consensus conference on Gleason grading of prostatic carcinoma: definition of grading patterns and proposal for a new grading system. Am J Surg Pathol 2016; 40: 244-52.

4. Mellinger GT, Gleason D, Bailar J. The histology and prognosis of prostatic cancer. J Urol 1967; 97: 331- 7.

5. Gleason DF, Mellinger GT. Prediction of prognosis for prostatic adenocarcinoma by combined histological grading and clinical staging. J Urol 1974; 111: 58-64.

6. Epstein JI, Allsbrook WC, Amin MB, et al. The 2005 International Society of Urological Pathology (ISUP) Consensus Conference on Gleason Grading of Prostatic Carcinoma. Am J Surg Pathol 2005; 29: $1228-42$.

7. Pierorazio PM, Walsh PC, Partin AW, Epstein JI. Prognostic Gleason grade grouping: Data based on the modified Gleason scoring system. BJU Int 2013; 111: 753-60.

8. Hamdy FC, Donovan JL, Lane JA,et al. ProtecT Study Group. 10-year outcomes after monitoring, surgery, or radiotherapy for localized prostate cancer.N Engl J Med 2016; 375: 1415-24.

9. Barocas DA, Alvarez J, Resnick MJ, et al. Association between radiation therapy, surgery, or observation for localized prostate cancer and patient-reported outcomes after 3 years. JAMA 2017; 317: 1126-40.

10. Ozok HU, Sagnak L, Tuygun C, et al. Will the modification of the Gleason grading system affect the urology practice? Int J Surg Pathol 2010; 18: 248-54.

11. Alenda O, Ploussard G, Mouracade P, et al. Impact of the primary Gleason pattern on biochemical recurrence-free survival after radical prostatectomy: a single-center cohort of 1.248 patients with Gleason 7 tumors. World J Urol 2010; 29: 671-6.

12. Billis A, Guimaraes MS, Freitas LL, et al. The impact of the 2005 international society of urological pathology consensus conference on standard Gleason grading of prostatic carcinoma in needle biopsies. J Urol 2008; 180: 548-52.

13. Helpap B, Egevad L. The significance of modified Gleason grading of prostatic carcinoma in biopsy and radical prostatectomy specimens. Virchows Arch 2006; 449: 622-7.

14. Tsivian M, Sun L, Mouraviev V, et al. Changes in Gleason score grading and their effect in predicting outcome after radical prostatectomy. Urology2009; 74: 1090-3.

15. Trock BJ, Guo CC, Gonzalgo ML, et al. Tertiary Gleason patterns and biochemical recurrence after prostatectomy: proposal for a modified Gleason scoring system. J Urol 2009; 182: 1364-70.

16. Pan CC, Potter SR, Partin AW, et al. The prognostic significance of tertiary Gleason patterns of higher grade in radical prostatectomy specimens: a proposal to modify the Gleason grading system. Am J Surg Pathol 2000; 24: 563-9.

17. AminA, Partin A, Epstein JI. Gleason score 7 prostate cancer on needle biopsy: relation of primary pattern 3 or 4 to pathological stage and progression after radical prostatectomy. J Urol 2011; 186: $1286-90$.

18. Wright JL, Salinas CA, Lin DW, et al. Prostate cancer specific mortality and Gleason 7 disease differences in prostate cancer outcomes between cases with Gleason $4+3$ and Gleason 3+4 tumours in a population based cohort. J Urol 2009; 182: 2702-7. 
19. Rasiah KK, Stricker PD, Haynes AM, et al. Prognostic significance of Gleason pattern in patients with Gleason score 7 prostate carcinoma. Cancer 2003; 98: 2560-5.

20. Mosse CA, Magi-Galluzzi C, Tsuzuki T, et al. The prognostic significance of tertiary Gleason pattern 5 in radical prostatectomy specimens. Am J Surg Pathol 2004; 28: 394-8.

21. Whittemore DE, Hick EJ, Carter MR, et al. Significance of tertiary Gleason pattern 5 in Gleason score 7 radical prostatectomy specimens. J Urol 2008; 179: 516-22.

22.Sabolch A, Feng FY, Daignault-Newton S, et al. Gleason pattern 5 is the greatest risk factor for clinical failure and death from prostate cancer after dose-escalated radiation therapy and hormonal ablation. Int J Radiat Oncol Biol Phys 2011; 81: 351-60. 